\title{
Effect of Cover Crops, and the Management Thereof, on the Weed Spectrum in a Drip-irrigated Vineyard: 1. Weeds Growing During Winter and From Grapevine Bud Break to Grapevine Berry Set
}

\author{
J.C. Fourie ${ }^{1 *}$, E.C. Kunjeku², M. Booyse ${ }^{3}$, T.G. Kutama² ${ }^{2}$ L.W. Sassman ${ }^{1}$
}

(1) ARC Infruitec-Nietvoorbij, Private Bag X5026, Stellenbosch, 7599, South Africa

(2) Department of Plant Production, School of Agriculture, University of Venda, Private Bag X5050, Thohoyandou, 0950, South Africa

(3) ARC Biometry, Private Bag X5026, Stellenbosch, 7599, South Africa

Submitted for publication: January 2017

Accepted for publication: April 2017

Key words: Mechanical weed control, chemical weed control, grapevines, soil surface management

\begin{abstract}
A five-year trial (2009 to 2013) was executed in a drip-irrigated full-bearing seven-year-old Shiraz/101-14 Mgt vineyard established on a sandy to sandy clay loam soil at Blaauwklippen Farm $\left(33^{\circ} 58^{\prime} \mathrm{S}, \mathbf{1 8}^{\circ} 50^{\prime} \mathrm{E}\right)$ near Stellenbosch, South Africa. Fourteen treatments, consisting of two management practices applied to five cover crop species, as well as winter-growing weeds (no cover crop) and winter-growing weeds (no cover crop) with nematicide applied in the vine row, were applied. The effect of the five cover crop species, either controlled chemically (CC) or mechanically (MC) during grapevine bud break, on the weed spectrum was determined at the end of winter and during grapevine berry set. Total suppression of Lolium species (ryegrass) was achieved with Avena sativa cv. Pallinup (oats) (CC) and Eruca sativa cv. Nemat (Nemat) (CC) after three years. A grass-specific herbicide applied at the end of May 2012 terminated the dominance of ryegrass and facilitated the dominance of Erodium moschatum (musk heron's bill). Sowing the cover crops as late as 2013-05-23 prevented ryegrass from regaining its dominance. After five winters, ryegrass was totally eradicated from oats (CC), oats (MC), Sinapus alba cv. Braco (white mustard) (CC) and Nemat (CC). Musk heron's bill was totally suppressed in all treatments during berry set within two seasons and ryegrass in all the $\mathrm{CC}$ treatments by 2011 . This probably facilitated the dominance of Digitaria sanguinalis (crab fingergrass).
\end{abstract}

\section{INTRODUCTION}

Effective weed control can be achieved by using grain and broadleaf annuals as cover crops for the biological control of weeds in the vineyards and orchards of South Africa (Fourie, 2005; Fourie et al., 2005; 2006; Fourie, 2010; Fourie et al., 2015). Facelli and Pickett (1991), as well as Shrestha et al. (2002), observed that the type of plant residue cover affected the weed species composition. Consequently, there is a need for future studies to document the response of the weed flora to different cover crops and their mulches (Dastgheib \& Frampton, 2000).

It has been reported that soil cultivation practices cause changes in the weed population (Teasdale et al., 1991; Buhler et al., 1997; De la Fuente et al., 1999; Swanton et al., 1999; Shrestha et al., 2002; Westra et al., 2008). In contrast to this, however, Wrucke and Arnold (1985) indicated that the distribution of broad-leaved weeds did not differ between conventional tillage and conservation tillage, while
Pollard and Cussans (1981), as well as Pollard et al. (1982), indicated an inconsistency in the weed response to tillage. Certain species are adapted to survive intermittent habitat disturbances (Smith, 1970) and will quickly fill the vacated niches created by a specific practice (Putnam, 1990). Légère and Samson (1999) observed that species dominance was brought about by interactions between crop rotation, weed management intensity and tillage. Consequently, situations where the weed population is dominated by a small number of species are indicative of a weed management system that creates conditions under which these species can flourish (Cousens \& Mortimer, 1995).

It is important to determine the effect of cover crops, and the management thereof, on the weed spectrum. In doing so, our understanding of long-term weed population dynamics under different soil cultivation practices can be improved, and the domination of the weed spectrum by problem weeds may be avoided.

*Corresponding author: E-mail address:fouriej@arc.agric.za

Acknowledgements: The authors thank the ARC, Winetech, Dried Fruit Technical Services and the National Research Foundation of South Africa (NRFTHRIP TP2009072100026), for financial support; K. Freitag, D. Mashamba, V.R. Nyamande, C.H. Ochse and I. van Huyssteen, for technical support; and Blaauwklippen Wine Estate, for supplying the trial site. Any opinions, findings and conclusions or recommendations expressed in any publication generated through THRIP-supported research are those of the authors and therefore the NRF/THRIP will not accept any liability in that regard 
The aim of this study therefore was to determine the effect of cover crops, selected for their bio-fumigation properties, on the weed spectrum at the end of winter and during grapevine berry set, when controlled chemically or incorporated mechanically into the topsoil during grapevine bud break in a drip-irrigated vineyard.

\section{MATERIALS AND METHODS}

\section{Experiment vineyard and layout}

The trial was conducted over five years (2009 to 2013) in a full-bearing seven-year-old Shiraz/101-14 Mgt vineyard established on a sandy ( 0 to $300 \mathrm{~mm}$ soil layer) to sandy clay loam soil (300 to $600 \mathrm{~mm}$ soil layer) at Blaauwklippen

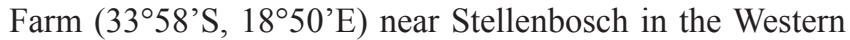
Cape, South Africa (Fourie et al., 2015). Fourteen treatments were applied (Table 1), consisting of two management practices applied to five cover crop species, as well as to two treatments in which no cover crop was sown, one in which a nematicide was applied in the vine row. Each replicate (experimental unit) covered an area of $81 \mathrm{~m}^{2}$. A work row and two vine rows functioned as a buffer zone between treatments in different work rows. A buffer, consisting of five vines, was left between the experimental vines of treatment plots situated in the same vine row.

The cover crops were established as described by Fourie et al. (2015) at the seeding densities indicated in Table 1. During the 2009/2010 to 2012/2013 seasons, the cover crops were sown annually during early May (seeding dates varying between 4 and 10 May) after the onset of the first good winter rain. The late onset of winter rain in 2013 resulted in the cover crops being established on 23 May. Fertilisers were applied as described by Fourie et al. (2015).

The cover crops were controlled between late bloom and early seed/pod formation, which coincided with grapevine bud break. Two management practices were applied. One practice consisted of full-surface post-emergence chemical weed control (CC), while the other consisted of slashing the above-ground growth and incorporating the macerated fibre mechanically into the top $200 \mathrm{~mm}$ soil layer (MC), as described by Fourie et al. (2015). In the last-mentioned practice, chemical weed control was applied to the vine row (one metre-wide strip). Full-surface chemical control applied during grapevine berry set was part of both management practices. The herbicide used just before bud break (first week of September) and during berry set (first week of December) was glyphosate at a dosage of $1800 \mathrm{~g} / \mathrm{L}$ per hectare. Fluazyfopbutyl, at a dosage of $625 \mathrm{~g} / \mathrm{L}$ per hectare, was applied full surface in all the treatments at the end of May 2012, except in the two oats treatments. This was done to prevent the Lolium species (ryegrass) from impacting negatively on the dry matter production (DMP) of the four broadleaf cover crops.

Grapevine cultivation practices conducted on this site were in keeping with the standard practices applied in the vineyards of South Africa. Supplementary drip irrigation was applied from December to March. The standard pest and disease management programme used by the farm was applied.

\section{Measurements}

Weed DMP was determined just before grapevine bud break (end of August) and during grapevine berry set (end of November) to determine weed dominance. In each plot (replication), one of the three grapevine inter-rows was randomly chosen and five $0.5 \mathrm{~m}^{2}$ quadrants were placed diagonally across the grapevine inter-row, spaced $0.7 \mathrm{~m}$ apart. The weed species were harvested separately by removing the above-ground growth and placing it in a paper bag. After the samples had been gathered in the field, the DMP was determined as described by Fourie et al. (2001).

TABLE 1

Treatments applied

\begin{tabular}{lcc}
\hline Cover crops & Management practice & Seeding density (kg/ha) \\
\hline Avena sativa L. cv. Pallinup (oats) & $\mathrm{CC}^{1}$ & 100 \\
Oats & $\mathrm{MC}^{2}$ & 100 \\
Sinapis alba cv. Braco (white mustard) & $\mathrm{CC}$ & 8 \\
White mustard & $\mathrm{MC}$ & 8 \\
Brassica napus cv. AVJade (canola) & $\mathrm{CC}$ & 8 \\
Canola & $\mathrm{MC}$ & 8 \\
Brassica juncea cv. Caliente 199 (Caliente) & $\mathrm{CC}$ & 10 \\
Caliente & $\mathrm{MC}$ & 10 \\
Eruca sativa cv. Nemat (Nemat) & $\mathrm{CC}$ & 5 \\
Nemat & $\mathrm{MC}$ & 5 \\
No cover crop (weeds) & $\mathrm{CC}$ & $\mathrm{NA}$ \\
Weeds & $\mathrm{MC}$ & $\mathrm{NA}$ \\
Weeds + nematicide (Rugby 10ME @ $15 \mathrm{~mL} / \mathrm{m}^{2}$ ) (weedsnem) & $\mathrm{CC}$ & NA \\
Weedsnem & $\mathrm{MC}$ & NA
\end{tabular}

${ }^{1}$ Full-surface chemical control from just before bud break to grapevine harvest. ${ }^{2}$ Chemical control in the vine row and mechanical incorporation of the weeds/cover crops in the work row just before bud break, CC from berry set. ${ }^{3}$ Not applicable 


\section{Statistical procedures}

The experiment was a complete randomised block design with 14 treatments (two management practices applied to five cover crop species, as well as to two treatments in which no cover crop was sown, one in which a nematicide was applied in the vine row) replicated three times. The experiment was repeated for five consecutive years. DMP was measured randomly within each experiment plot at the end of August and at the end of November. The data were tested for normality (Shapiro \& Wilk, 1965), found to be acceptably normally distributed, and subjected to analysis of variance. Analyses of variance were performed according to the treatment design for each season separately, using the General Linear Models Procedure (PROC GLM) of SAS software (Version 9.2; SAS Institute Inc, Cary, USA). Fisher's least significant difference was calculated at the 5\% level to compare treatment means (Ott \& Longnecker, 2001).

\section{RESULTS AND DISCUSSION}

\section{Effect of treatments on the composition of the winter weed population just before grapevine bud break 2009}

At the end of the first winter in which the cover crops were established in the grapevine inter-row (work row), the ryegrass was either the dominant or next to dominant species in all the treatments, with the exception of Avena sativa cv. Pallinup (oats) (CC), Sinapis alba cv. Braco (white mustard) (MC) and Brassica juncea cv. Caliente 199 (Caliente) (MC) (Table 2). The stand of ryegrass in the two oats treatments and white mustard (MC) was lower than that of the treatment in which no cover crop was sown (weeds) and the weeds treatment in which a nematicide was applied during bud break (weedsnem), indicating effective suppression of the species at this time. Raphanus raphanistrum (wild radish) was the most dominant species in the two oats treatments, while Oxalis pes-caprae (yellow sorrel) dominated the CC treatments of white mustard, Brassica napus cv. AVJade (canola), Caliente and the two Eruca sativa cv. Nemat (Nemat) treatments. In common practice, wild radish and yellow sorrel are easy to control chemically, while ryegrass has the tendency to become resistant to glyphosate and paraquat, as well as to other grass-specific herbicides. The Vicia species dominated Caliente (MC) and white mustard (MC), with the stand in Caliente (MC) being significantly more than that observed for all the weeds in all the treatments, with the exception of ryegrass in weeds (MC). The Vicia species, however, are N-fixers and are also used as cover crops on sandy soils (Fourie et al., 2001; 2005).

\section{0}

Ryegrass dominated all the treatments in which $\mathrm{MC}$ was applied, with the exception of oats (MC) (Table 3). For each cover crop species the ryegrass stand was higher in the MC treatment than in the $\mathrm{CC}$ treatment, with the exception of oats. Although not significant, the same trend was observed for oats. The ryegrass stand in weeds (MC) and weedsnem (MC) was also higher than that of weeds (CC) and weedsnem (CC). This is an indication that the weed control method applied during grapevine bud break influenced the ryegrass stand during the following winter. The ryegrass stand in the treatments where the cover crops were combined with $\mathrm{CC}$, as well as with oats (MC), was lower than that of all the treatments in which no cover crop was sown. This is an indication that oats per se suppressed the ryegrass effectively, whereas the other species had to be combined with chemical control during bud break to achieve effective suppression. Similar to the 2009 season, wild radish was the dominant species in the two oats treatments. This weed became more prevalent in the canola, Nemat and weedsnem treatments, while dominating weeds (CC). During this season, the stand of yellow sorrel decreased in all the treatments, with the exception of canola (CC). In white mustard (CC) it was reduced from being dominant to full eradication. Erodium moschatum (musk heron's bill) remained the next to dominant species in oats (MC), whilst becoming next to dominant in white mustard $\mathrm{CC}$, white mustard (MC) and weeds (CC). This species also became the dominant species in weedsnem (CC) and Caliente (CC). Euphorbia peplus (stinging milkweed) was observed in all the treatments for the first time and was the dominant species in Nemat (CC) and the next to dominant species in oats (CC).

\section{1}

Ryegrass remained dominant in the MC treatments of Caliente, Nemat and weeds (Table 4). As in 2010, the ryegrass stand for each cover crop species was higher in the $\mathrm{MC}$ treatment than in the $\mathrm{CC}$ treatment (Table 4). This supports the observation that CC plays a major role in the suppression of ryegrass during winter. During this season, the absence of ryegrass in oats (CC) and Nemat (CC) indicated total control. Similar to the previous two seasons, wild radish was the dominant species in oats (CC) and oats (MC) (Tables 2 to 4 ). Wild radish became the dominant species in canola (MC), canola (CC) and Nemat (CC) (Table 4). Musk heron's bill remained dominant in weedsnem $(\mathrm{CC})$ and the next to dominant species in oats (MC) and white mustard (CC). This weed became dominant in weeds (CC), and the next to dominant species in oats (CC), canola (CC) and Nemat (CC). It therefore seemed as if a trend was developing in which musk heron's bill was starting to manifest its dominance in the CC treatments, with the exception of Caliente. Although yellow sorrel occurred in all the treatments, it did not dominate in any of the treatments (Table 4), which is in contrast to the previous two seasons (Tables 2 and 3). Although stinging milkweed was once again present in all the treatments (Table 4), the species lost its dominance in Nemat (CC) and became dominant in white mustard (MC). However, as in the previous season, no definite trends could be detected.

\section{2}

Musk heron's bill became the dominant species in all the treatments with the exception of canola (MC), in which it was the third most prevalent species, as well as Nemat (MC) and weedsnem (MC), in which it was the next to dominant species (Table 5). In the case of the two oats treatments, it replaced wild radish, which had dominated during the previous three seasons (Tables 2 to 4). The application of a grass-specific herbicide in all the treatments, except the two oats treatments, approximately two weeks after sowing 


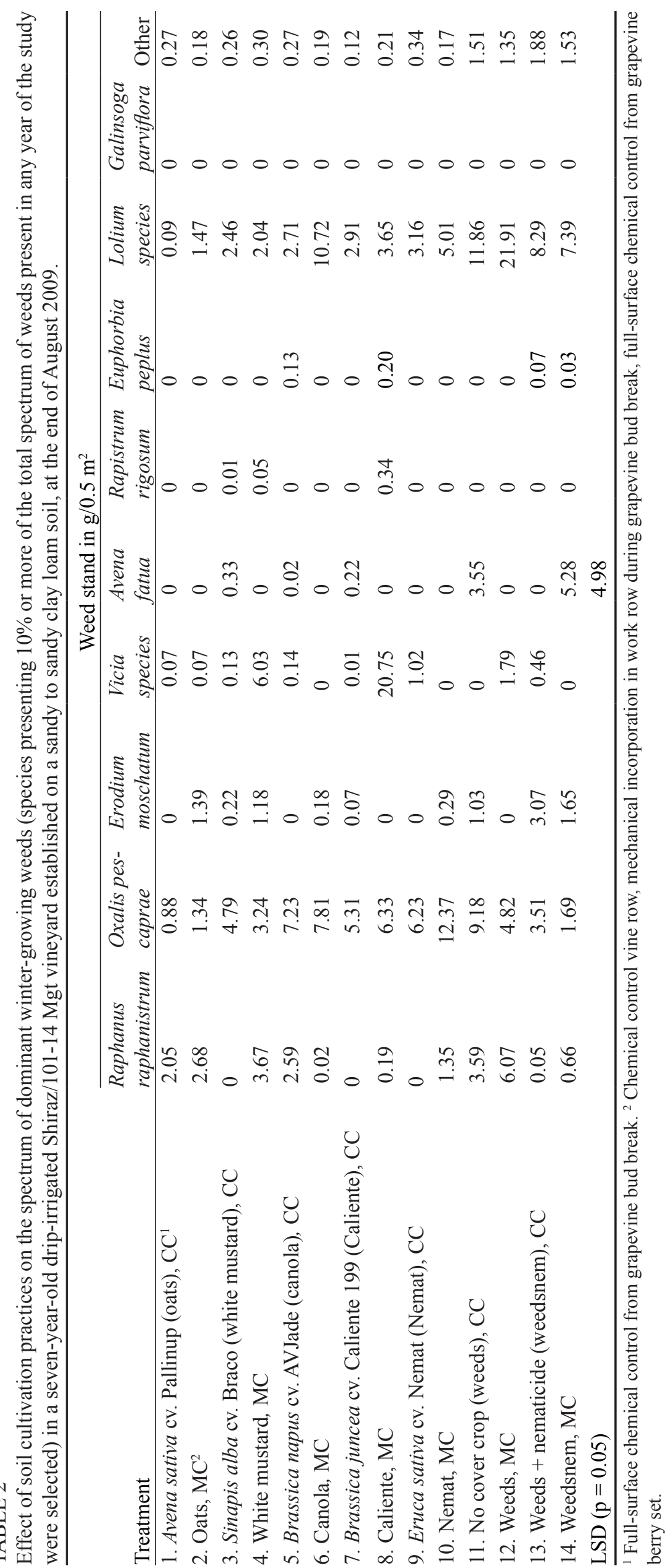




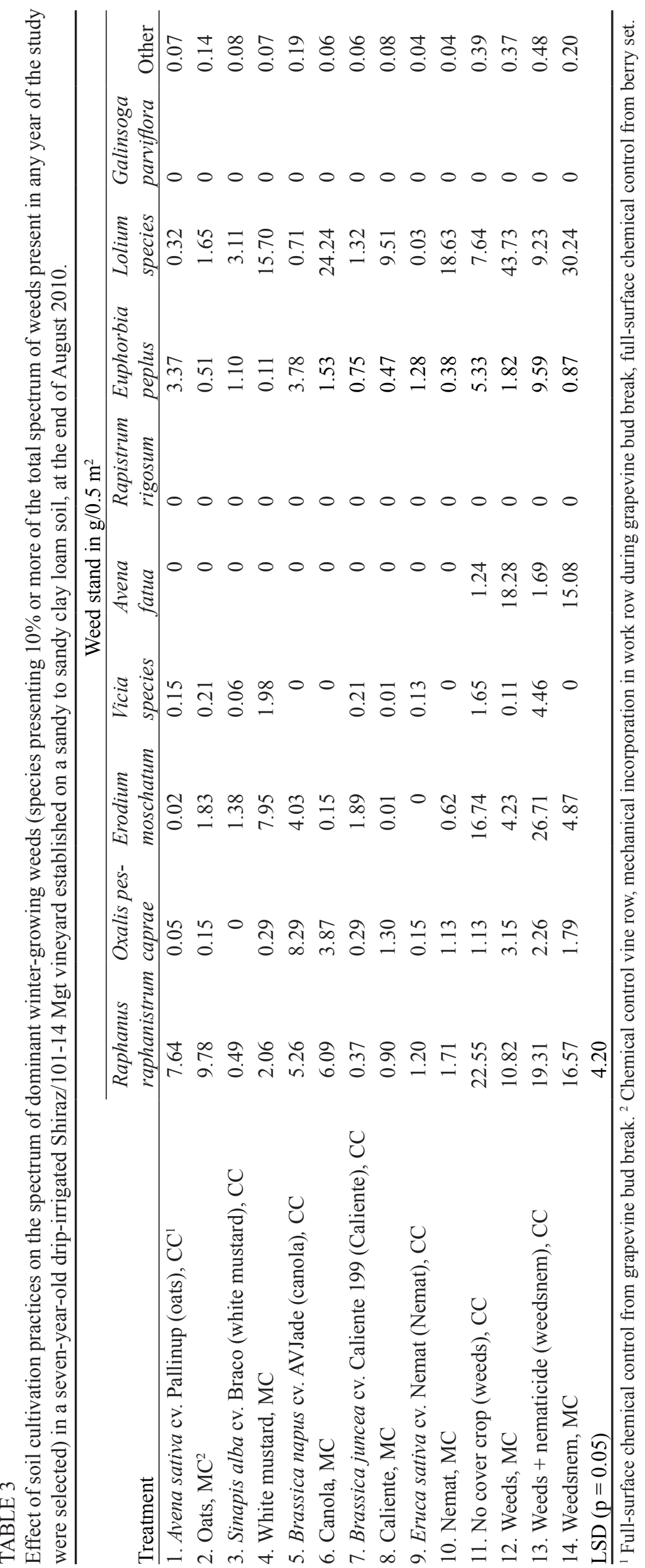




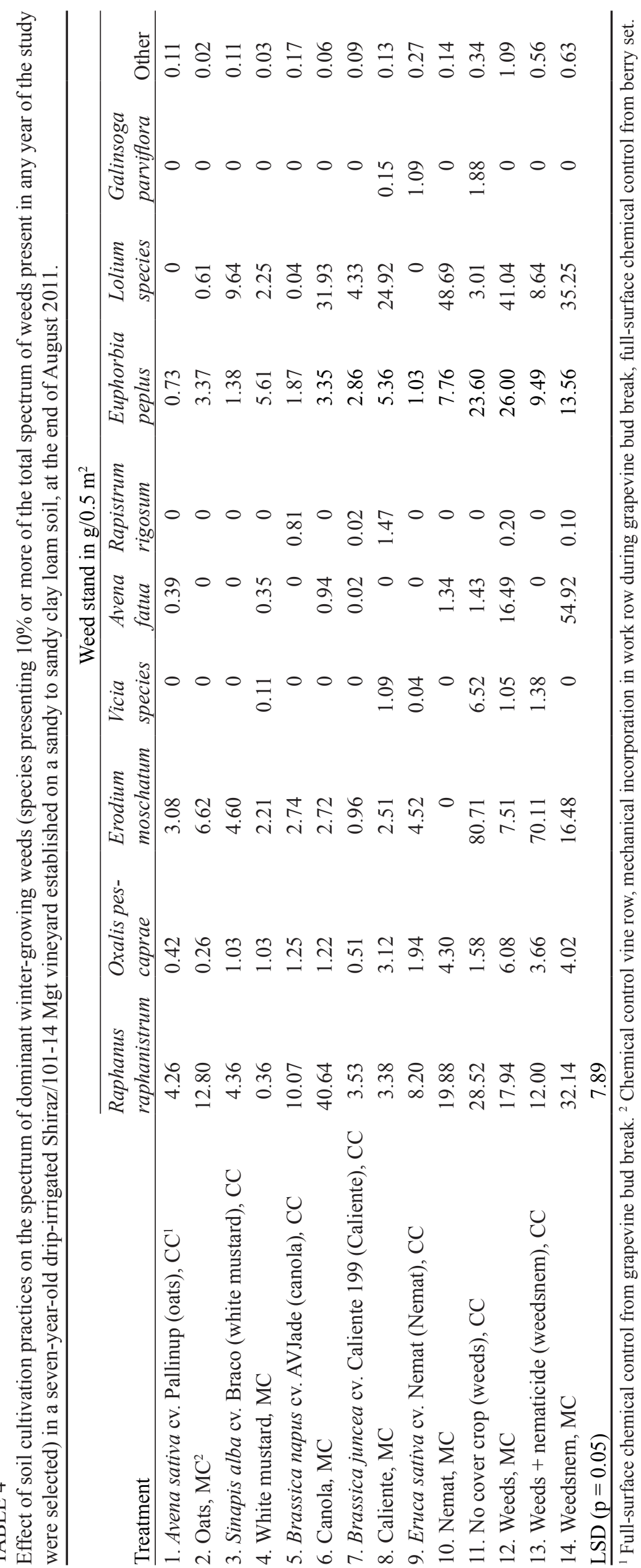




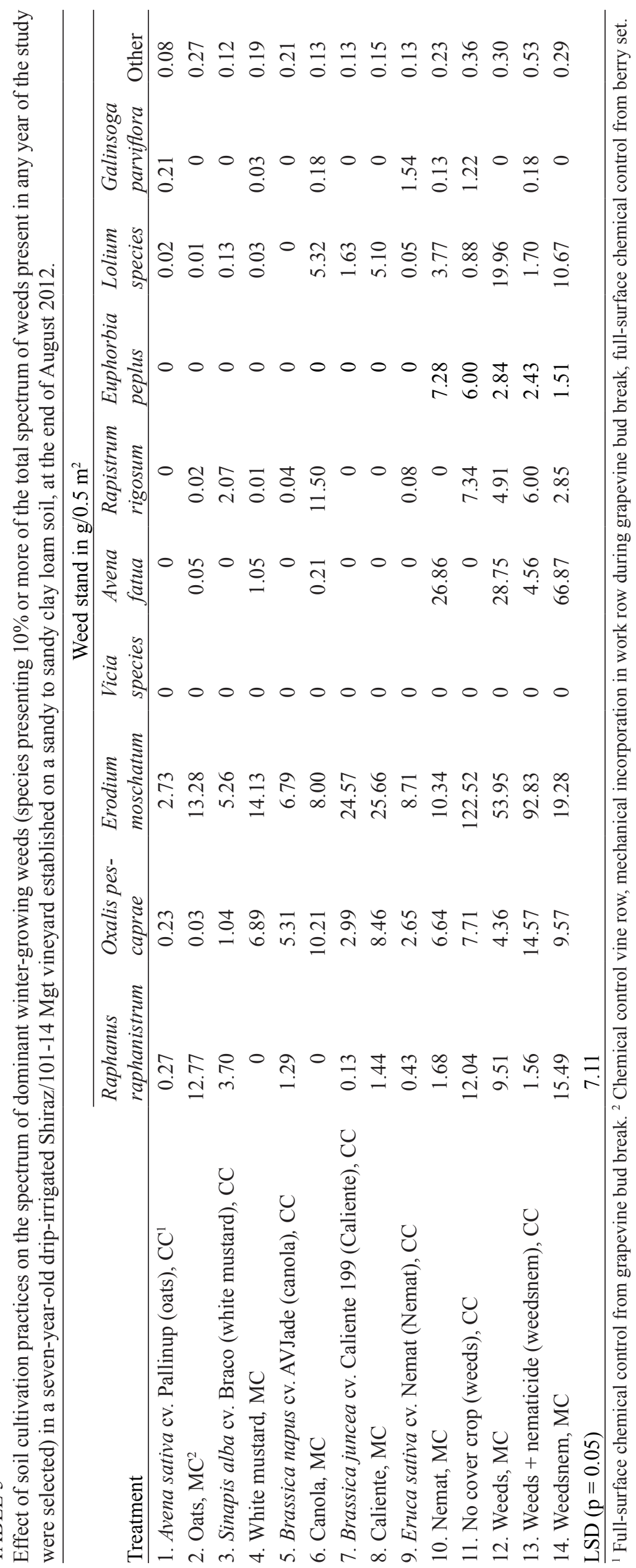


the cover crops (end of May) terminated the dominance of ryegrass in most of these treatments (Table 5). The chemical control of ryegrass during autumn therefore most probably facilitated the dominance of musk heron's bill in all the treatments, with the exception of the two oats treatments. This supports the results of Teasdale et al. (1991), Buhler et al. (1997), De la Fuente et al. (1999), Swanton et al., (1999), Shrestha et al. (2002) and Westra et al. (2008). Stinging milkweed disappeared from all the cover crop treatments, with the exception of Nemat (MC). From 2010 onwards, the stand of Avena fatua (wild oats) in weeds (MC) and weedsnem (MC) was always higher than that in the other treatments, with the exception of Nemat (MC) (Tables 3 to 5 ). Wild oats dominated the weed spectrum in weedsnem from 2011 (Tables 4 and 5) and in Nemat (MC) during 2012 (Table 5). It was also the next to dominant species in weeds (MC) during 2010 and 2012 (Tables 3 and 5). Rapistrum rigosum (wild mustard) dominated the weed spectrum in canola (MC), after being absent from this treatment during the previous three seasons (Tables 2 to 5).

\section{3}

Musk heron's bill remained the dominant or next to dominant species in all the treatments (Table 6). It seems that because the cover crops were established as late as 23 May during this season prevented the ryegrass from regaining its dominance in any treatment. Ryegrass was totally eradicated from oats (CC), oats (MC), white mustard (CC) and Nemat (CC). Wild radish dominated oats $(\mathrm{MC})$, canola $(\mathrm{MC})$ and Nemat (MC), while wild oats remained dominant in weedsnem (MC) (Table 6), as in the previous two seasons (Tables 4 and 5). Galinsoga parviflora (gallant soldier) appeared in both Nemat (CC) and weeds (CC) for the first time during the 2011 season and remained in these treatments during 2012 and 2013 (Tables 2 to 6). This species was the third most prevalent species in Nemat (CC) during 2012 and became dominant in 2013 (Tables 4 to 6). In the case of weeds (CC), the species became the next to dominant during 2013 (Table 6).

\section{Effect of treatments on the composition of the summer weed population at grapevine berry set 2009}

During this first season of application, either musk heron's bill or ryegrass dominated the weed spectrum in all the treatments at the end of November (Table 7). Wild radish was the only other species present in all the treatments. It was the next to dominant weed in oats (MC), white mustard (MC), weeds (MC), weedsnem (MC) and weedsnem (CC). The stand of wild radish exceeded the non-classified weeds (other) only in weedsnem (MC).

\section{0}

The stand of musk heron's bill was reduced from being either the dominant or next to dominant species in 2009 (Table 7) to total suppression in the two oats and two Caliente treatments, as well as in white mustard (MC), canola (MC) Nemat (MC) and weedsnem (CC) in the 2010/2011 season (Table 8). This species, however, remained dominant in canola (CC) and was still the next to dominant species in weeds (CC) (Table 8), despite the drastic reduction in the stand of this weed in these two treatments from 2009 to 2010 (Tables 7 and 8).

Ryegrass remained the dominant species in canola (MC) and Caliente (MC) (Tables 7 and 8) and became the dominant species in white mustard (MC), Nemat (MC) and weedsnem (MC) (Table 8). It was also the next to dominant species in weeds (MC). A trend was establishing, in which the stand of ryegrass in the MC treatment of a species always exceeded that of the $\mathrm{CC}$ treatment of the same species. With the exception of oats, this difference was significant. Ryegrass was suppressed totally from grapevine bud break to grapevine berry set by all the $\mathrm{CC}$ treatments, with the exception of white mustard (CC) and weedsnem (CC). This management practice therefore can play an important role in the control of this problem weed. Wild radish remained the next to dominant weed in white mustard (MC) and weedsnem (MC) (Tables 7 and 8). This species also filled the niche left by musk heron's bill and, to a lesser extent, by ryegrass, by dominating the weed spectrum in both the oats treatments and both the weeds treatments, as well as white mustard (CC), Nemat (CC) and weedsnem (CC) (Table 7). Although Tribulus terrestris (common dubbeltjie) and Digitaria sanguinalis (crab fingergrass) infested most of the treatments during 2010, common dubbeltjie was the most aggressive, dominating Caliente (CC) within a season (Tables 7 and 8). Common dubbeltjie also became the next to dominant species in oats (MC), white mustard (CC), Nemat (CC) and Caliente (MC) (Table 8).

\section{1}

With the exception of oats (MC), musk heron's bill was suppressed totally in all the treatments during 2011 (Table 9). Ryegrass was totally suppressed from grapevine bud break to grapevine berry set by all the $\mathrm{CC}$ treatments. The stand of this species was also reduced in all the MC treatments compared to the stand observed in the previous season (Tables 8 and 9). However, ryegrass remained dominant in white mustard (MC) and Nemat (MC) (Table 9). This species was also the next to dominant species in canola (MC), weeds (MC) and weedsnem (MC). The trend observed during 2010, in which the stand of ryegrass in the MC treatment of a species always exceeded that of the CC treatment of the same species, was once again observed, even though it was only significant for Nemat (Tables 8 and 9). This confirmed that CC can play an important role in the control of ryegrass. Wild radish remained dominant in oats (MC), weeds (MC) and white mustard (MC) (Tables 8 and 9). Wild radish also became dominant in canola (MC), Caliente (MC) and weedsnem (MC) (Table 9). However, this species was totally suppressed in white mustard (CC), for the second consecutive season, and in Nemat (CC), with crab fingergrass becoming dominant in these treatments (Tables 8 and 9). In contrast to the previous season, crab fingergrass also dominated the weed spectrum in canola (CC), Caliente (CC) and weeds (CC) (Tables 8 and 9). It seems that the application of CC during grapevine bud break facilitated the dominance of crab fingergrass during grapevine berry set. No definite trend was observed for common dubbeltjie. This 


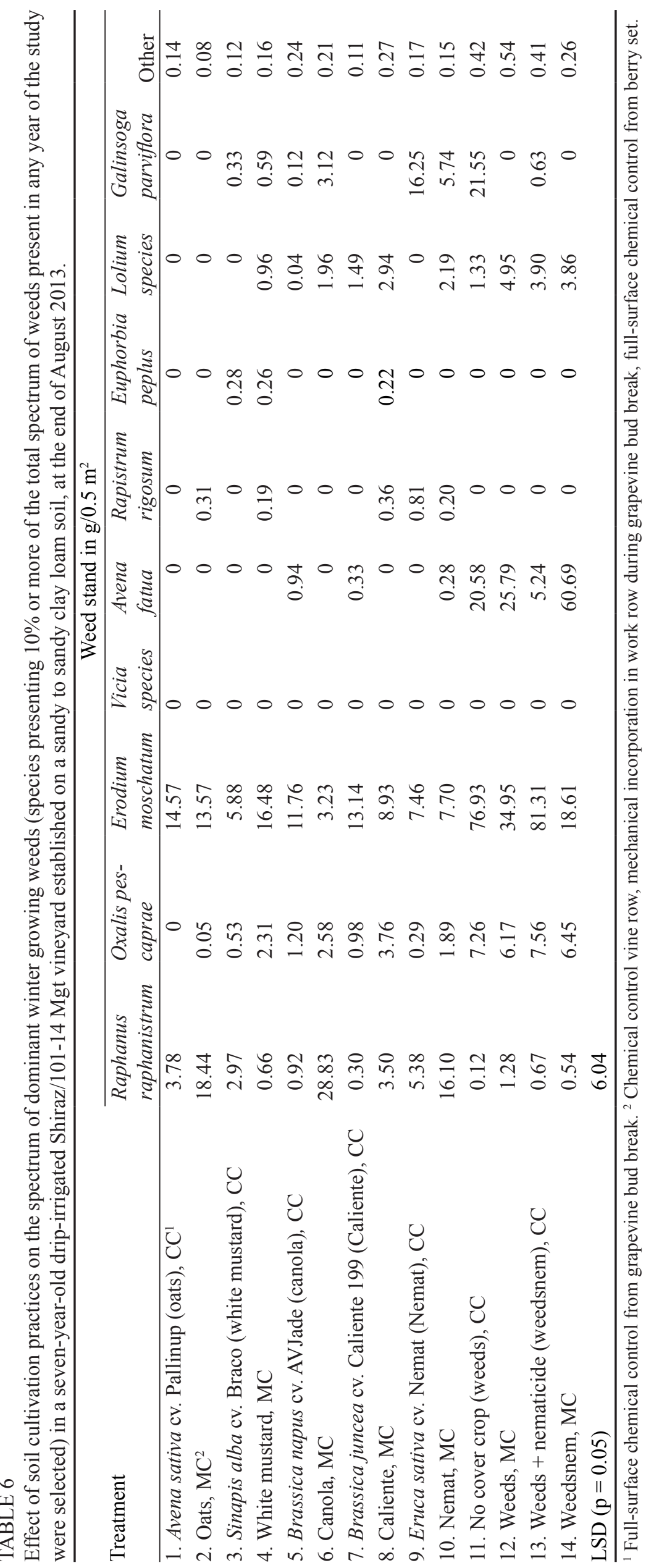




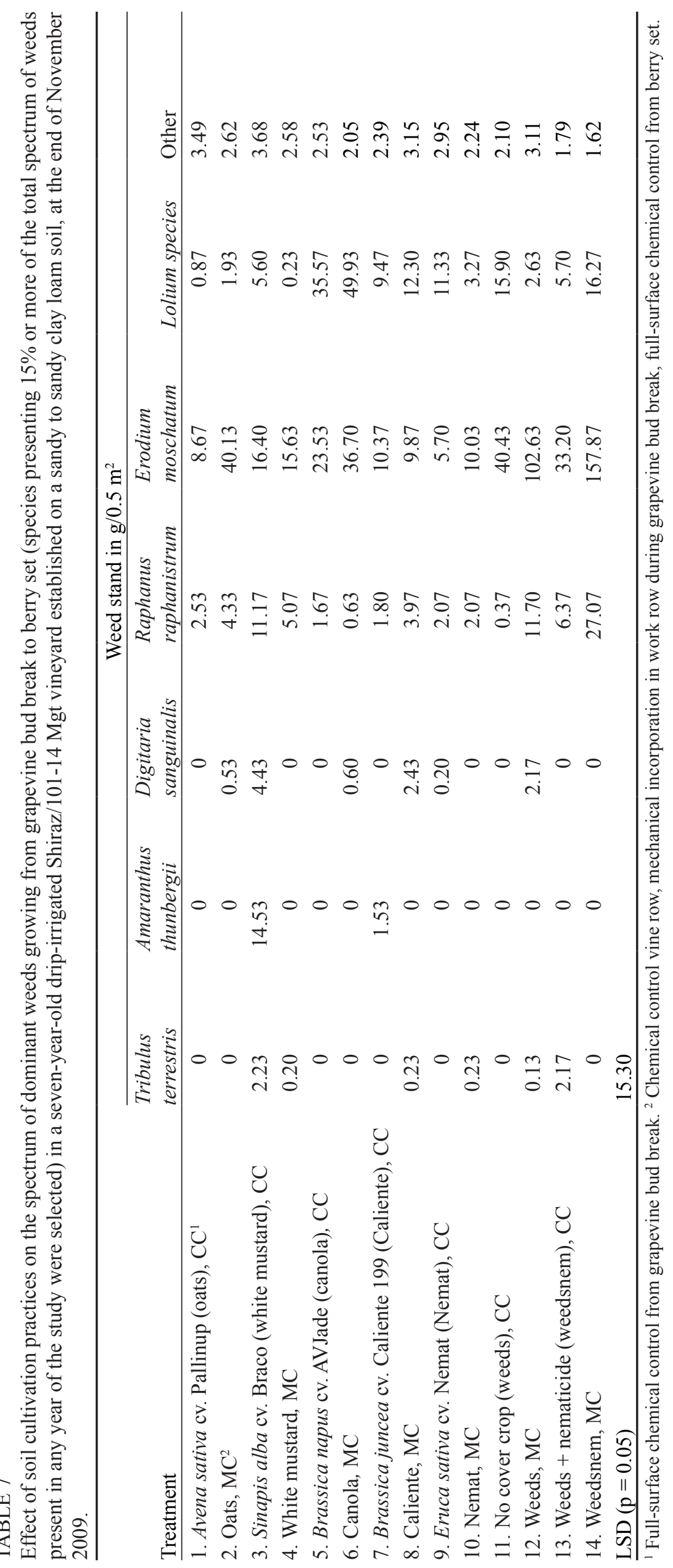




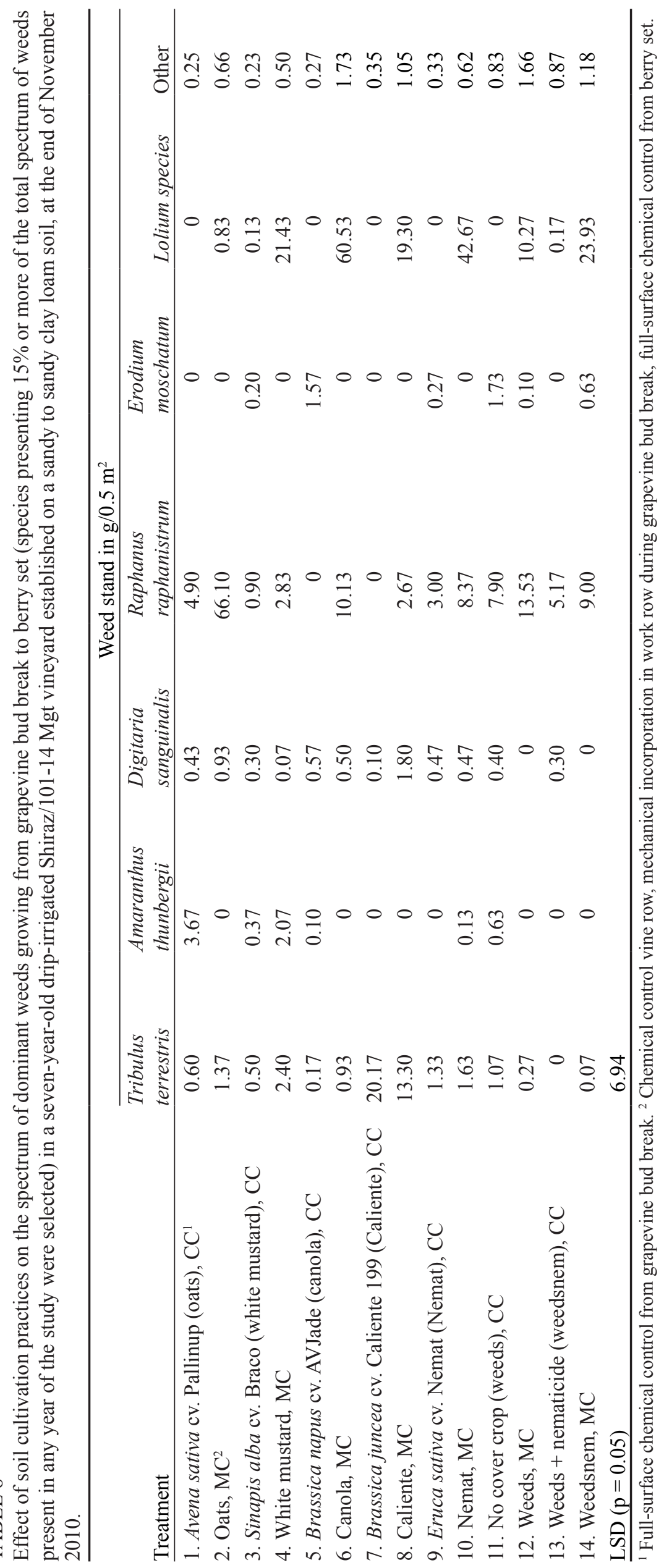




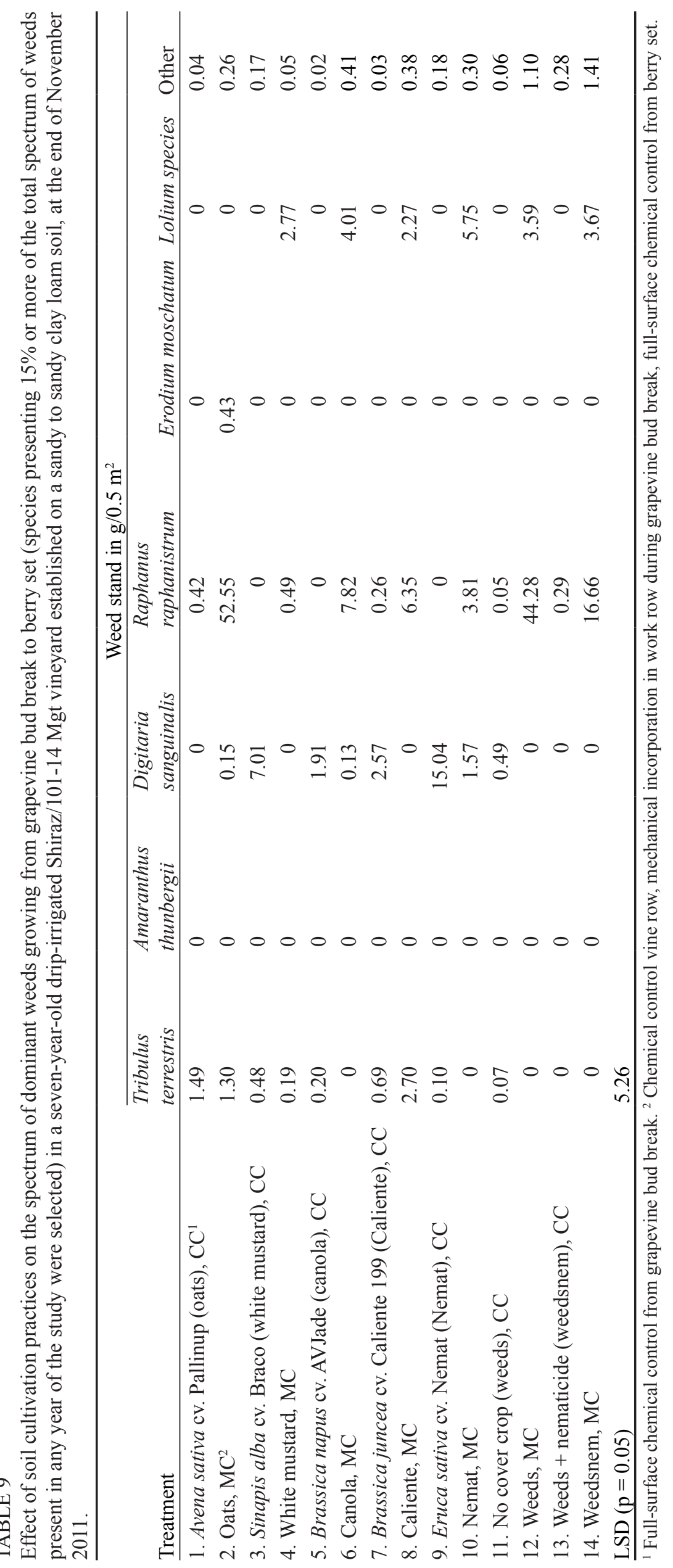




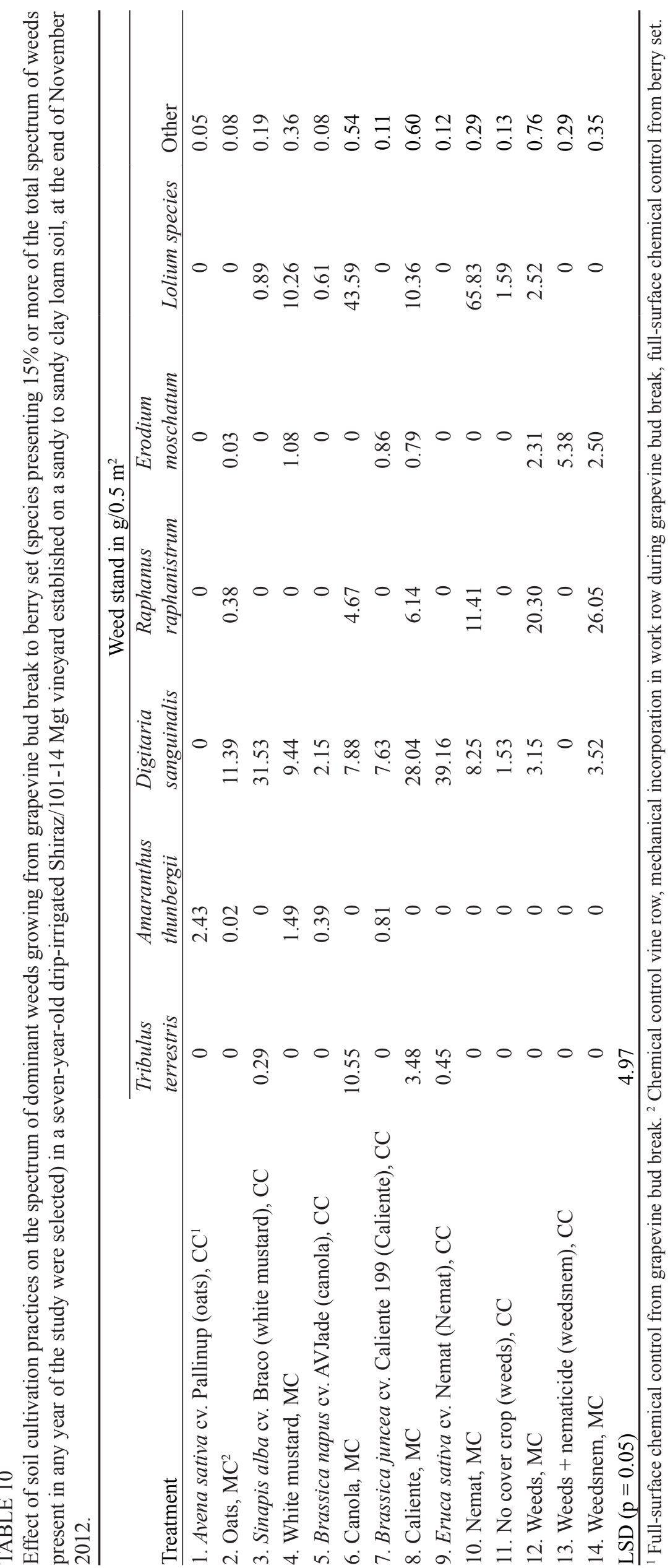


weed, however, became dominant in oats $(\mathrm{CC})$ and was the next to dominant species in oats (MC), canola (CC), the two Caliente treatments and weeds (CC) (Table 9).

\section{2}

Musk heron's bill regained dominance in weedsnem (CC) (Table 10). Ryegrass was suppressed totally for the third consecutive season in oats (CC), Caliente (CC) and Nemat (CC), as well as for the second consecutive season in oats (MC) and weedsnem (CC) (Tables 8 to 10). Although total control could not be achieved with white mustard (CC) and canola (CC), the ryegrass stand was significantly lower than that of the corresponding MC treatment (Table 10). The trend that occurred during 2010 and 2011 was once again observed for the third consecutive season (Tables 8 to 10). It therefore can be accepted that CC plays an important role in the control of ryegrass. Wild radish remained dominant in weeds (MC) and weedsnem (MC) (Tables 9 and 10). This species also remained next to dominant in oats (MC) and Nemat (MC). Wild radish, however, was totally suppressed in all the CC treatments (Table 10), this being the third consecutive season in canola (CC) and the second consecutive season in white mustard (CC) and Nemat (CC) (Tables 8 to 10). Total suppression of this species was also achieved with white mustard (MC) (Table 10). The dominance of crab fingergrass, which was first observed in the CC treatments of white mustard, canola, Caliente and Nemat at the end of November 2011 (grapevine berry set), was also observed at the end of November 2012 (Tables 9 and 10). This species also dominated oats (MC) and Caliente (MC) for the first time and was next to dominant in white mustard (MC), weeds (MC), weeds (CC) and weedsnem (MC).

\section{CONCLUSIONS}

Within one winter, ryegrass can be effectively suppressed by oats and white mustard. During the following two seasons, it was observed that post-emergence chemical control just before grapevine bud break played a major role in lowering the stand of ryegrass during the following season. Total suppression of ryegrass was achieved in the CC treatments of oats and Nemat in the third year of application. The dominance of ryegrass was terminated in 2012 (fourth season) by the application of a grass-specific herbicide approximately a fortnight after sowing the broadleaf cover crops (end of May). The chemical control of ryegrass most probably facilitated the dominance of musk heron's bill. The cover crops, which were established as late as 23 May during 2013, prevented the ryegrass from regaining its dominance in any treatment. After five winters, ryegrass was totally eradicated from oats (CC), oats (MC), white mustard (CC) and Nemat (CC).

During the first season of implementation, either musk heron's bill or ryegrass dominated the weed spectrum during grapevine berry set (early summer). Musk heron's bill was totally suppressed in all the treatments during berry set within two seasons. Ryegrass was suppressed totally during berry set in all the CC treatments by 2011 . This trend persisted in the CC treatments of oats, Caliente and Nemat during 2012. It therefore can be accepted that CC plays an important role in the control of this problem weed from bud break to berry set. It seems that the application of $\mathrm{CC}$ facilitated the eventual dominance of crab fingergrass during grapevine berry set.

The elimination or suppression of one species led to the dominance of another. This supports previous studies indicating that soil cultivation practices cause changes in the weed population, as well as the view that certain species are adapted to survive intermittent habitat disturbances and will quickly fill the vacated niches.

The above-mentioned illustrates the importance of studies in which not only the weed stand in general is evaluated, but where the weed spectrum is also analysed to provide information on weed dominance and population shifts that is crucial to decision making concerning weed control in the medium to long term.

\section{LITERATURE CITED}

Buhler, D.D., Hartzler, R.G. \& Forcella, F., 1997. Implications of weed seedbank dynamics to weed management. Weed Sci. 50, 329-336.

Cousens, R. \& Mortimer, M., 1995 ( $1^{\text {st }}$ ed). Dynamics of weed populations. Cambridge University Press, Cambridge.

Dastgheib, F. \& Frampton, C., 2000. Weed management practices in apple orchards and vineyards in the south island of New Zealand. New Zealand J. Crop \& Hort. Sci. 28, 53-58.

De la Fuente, E.B., Suàrez, S.A., Ghersa, C.M. \& Leòn, R.J.C., 1999. Soybean weed communities: Relationship with cultural history and corn yield. Agron. J. 91, 234-241.

Facelli, J.M. \& Pickett, S.T.A., 1991. Plant litter: Its dynamics and effects on plant community structure. Bot. Review 57, 1-32.

Fourie, J.C., 2005. Cover crop management in the vineyards of the Lower Orange River region, South Africa: 1. Performance of grass and broadleaf species. S. Afr. J. Enol. Vitic. 26, 140-146.

Fourie, J.C., 2010. Soil management in the Breede River Valley wine grape region, South Africa. 1. Cover crop performance and weed control. S. Afr. J. Enol. Vitic. 31, 14-21.

Fourie, J.C., Kruger, D.H.M. \& Malan, A.P., 2015. Effect of management practices applied to cover crops with bio-fumigation properties on cover crop performance and weed control in a vineyard. S. Afr. J. Enol. Vitic. 36, $146-153$.

Fourie, J.C., Louw, P.J.E. \& Agenbag, G.A., 2001. Effect of seeding date on the performance of grasses and broadleaf species evaluated for cover crop management in two wine grape regions of South Africa. S. Afr. J. Plant Soil $18,118-127$.

Fourie, J.C., Louw, P.J.E. \& Agenbag, G.A., 2005. Cover crop management in a Sauvignon blanc/Ramsey vineyard in the semi-arid Olifants River Valley, South Africa. 1. Effect of management practices on selected grass and broadleaf species. S. Afr. J. Enol. Vitic. 26, 131-139.

Fourie, J.C., Louw, P.J.E. \& Agenbag, G.A., 2006. Cover crop management in a Chardonnay/99 Richter vineyard in the Coastal wine grape region, South Africa. 1. Effect of two management practices on selected grasses and broadleaf species. S. Afr. J. Enol. Vitic. 27, 167-177.

Légère, A. \& Samson, D.N., 1999. Relative influence of crop rotation, tillage and weed management on weed associations in spring barley cropping systems. Weed Sci. 47, 112-122.

Ott, R.L. \& Longnecker M., 2001 (5 $5^{\text {th }}$ ed). An introduction to statistical methods and data analysis. Belmont, CA: Duxbury Press. 
Pollard, F. \& Cussans, G.W., 1981. The influence of tillage on the weed flora in a succession of winter cereal crops on a sandy loam soil. Weed Res. 21, 185-190.

Pollard, F., Moss, S.R., Cussans, G.W. \& Froud-Williams, R.J., 1982. The influence of tillage on the weed flora in a succession of winter wheat crops on a clay loam soil and a silt loam soil. Weed Res. 22, 129-136.

Putnam, A.R., 1990. Vegetable weed control with minimal herbicide inputs. HortSci. 25, 155-159.

Shapiro, S.S. \& Wilk, M.B., 1965. An analysis of variance test for normality (complete samples). Biometrika 52, 591-611.

Shrestha, A., Knezevic, S.Z., Roy, R.C. \& Ball-Coelho, B.R., 2002. Effect of tillage, cover crop and crop rotation on the composition of weed flora in a sandy soil. Weed Res. 42, 76-87.
Smith, A.G., 1970. The influence of Mesolithic and Neolithic man on British vegetation: A discussion. In: D. Walker \& R.G. West (eds). Studies in the vegetational history of the British Isles. Cambridge University Press, Cambridge. pp. $81-96$.

Swanton, C.J., Shrestha, A., Knezevic, S.Z., Roy, R.C. \& Ball-Coelho, B.R., 1999. Effect of tillage system, N, and cover crop on the composition of weed flora. Weed Sci. 47, 454-461.

Teasdale, J.R., Beste, C.E. \& Potts, W.E., 1991. Response of weeds to tillage and cover crop residue. Weed Sci. 39, 195-199.

Westra, P., Wilson, R.G., Miller, S.D., Stahlman, P.W., Wicks, G.W., Chapman, P.L., Withrow, J., Legg, D., Alford, C. \& Gaines, T.A., 2008. Weed population dynamics after six years under glyphosate- and conventional herbicide-based weed control strategies. Crop Sci. 48, 1170-1177.

Wrucke, M.A. \& Arnold, E., 1985. Weed species distribution as influenced by tillage and herbicides. Weed Sci. 33, 853-856 